\title{
GlyPhOSATE HeRBICIDE USE IN Urochloa brizantha MANAGEMENT IN INTERCROPPING WITH HERBICIDE-RESISTANT MAIZE ${ }^{1}$
}

\author{
Uso do Glyphosate no Manejo de Urochloa brizantha em Consórcio com Milho Resistente ao \\ Herbicida
}
SILVA, D.V. ${ }^{2}$, FREITAS, M.A.M. ${ }^{3}$, SOUZA, M.F. ${ }^{4}$, QUEIROZ, G.P. ${ }^{4}$, MELO, C.A.D. ${ }^{5}$, SILVA, A.A. ${ }^{4}$, FERREIRA, L.R. ${ }^{4}$, and REIS, M.R. ${ }^{5}$

\begin{abstract}
The success of the intercropping among cultivated species depends on the adoption of practices that provide, in due course, greater competitive ability of a species over another. The objective of this study was to evaluate the use of glyphosate herbicide in the suppression of Brachiaria (signalgrass) intercropped with maize. The experiment was conducted in a randomized complete block design with four replications. The treatments were arranged in a $5 \times 2+2$ factorial arrangement, the first factor corresponding to the doses of glyphosate $\left(48,96,144,240,480 \mathrm{~g} \mathrm{ha}^{-1}\right.$ of the acid equivalent (a.e)) and the second one to the vegetative stages of the signalgrass at the time of application ( 2 and 4 tillers). Two controls were added to the treatment list, comprising controls without herbicide application and hand removal of the signalgrass. The number of plants, tillers and dry matter of signalgrass was reduced with glyphosate. The increase of the glyphosate doses enhanced the injure to the forage plants, mainly when the compound was sprayed at the two-tiller vegetative stage. The dry matter of maize plants increased proportionally to the glyphosate dose. However, the height of the maize plants was not affected. The grain mass and productivity of maize grain increased with increasing dose of glyphosate. The maize yield was negatively influenced on the untreated control. Glyphosate at 96 and $144 \mathrm{~g} \mathrm{ha}^{-1}$, when applied at 2 and 4 tiller stage, respectively, reduces the growth of signalgrass and does not affect the maize grain yield.
\end{abstract}

Keywords: Zea mays, Urochloa brizantha, crop-livestock integration.

RESUMO - O sucesso do consórcio entre espécies cultivadas depende da adoção de práticas que proporcionem, em momento oportuno, maior habilidade competitiva a uma espécie em detrimento da outra. O objetivo deste trabalho foi avaliar o uso do glyphosate no manejo da braquiária em consórcio com o milho. O experimento foi realizado em delineamento de blocos casualizados com quatro repetições. Os tratamentos foram arranjados em esquema fatorial $5 \times 2+2$, sendo o primeiro fator correspondente às doses do herbicida glyphosate (48, 96, 144, 240, $480 \mathrm{~g} \mathrm{ha}^{-1}$ do equivalente ácido (e.a.)), e o segundo, aos estádios vegetativos da braquiária no momento da aplicação (dois e quatro perfilhos). Foram adicionadas duas testemunhas, constituidas pela testemunha capinada e pela testemunha sem aplicação do herbicida. O número de plantas e o de perfilhos, bem como a matéria seca da braquiária, foram reduzidos com a aplicação do glyphosate. O aumento das doses de glyphosate causou maior intoxicação da forrageira, que foi mais sensivel ao herbicida no estádio vegetativo de dois perfilhos. A matéria seca do milho foi maior nas maiores doses do glyphosate. Todavia, a altura das plantas não foi afetada. O peso de mil grãos e a produtividade de grãos do milho aumentaram com o incremento da dose do glyphosate. A ausência de aplicação influenciou negativamente a colheita do milho. Conclui-se que as dose de 96 e $144 \mathrm{~g} \mathrm{ha}^{-1}$ e.a., quando aplicadas no estádio de dois e quatro perfilhos, respectivamente, reduz o crescimento da braquiária e não afeta a produtividade de grãos do milho.

Palavras-chave: Zea mays, Urochloa brizantha, integração lavoura-pecuária.

Recebido para publicação em 5.6.2015 e aprovado em 8.7.2015.

2 Universidade Federal Rural do Semi-Árido, Mossoró, RN, Brasil, <danielvaladaos@yahoo.com.br>; ${ }^{3}$ Instituto de Educação, Ciência e Tecnologia Goiano, Posse, GO, Brasil; ${ }^{4}$ Universidade Federal de Viçosa, Viçosa, MG, Brasil; ${ }^{5}$ Universidade Federal de Viçosa, Campus Rio Paranaíba, Rio Paranaíba, MG, Brasil.

Planta Daninha, Viçosa-MG, v. 34, n. 1, p. 133-141, 2016 


\section{INTRODUCTION}

The Integrated Crop-Livestock Systems (ICLS) is defined as diversification, rotation, intercropping and succession of agriculture and livestock activities on a farm (Costa et al., 2012). This system, combined with direct seeding, involves conservation practices that allow to maximize land use, since this is explored throughout the year, enabling both greater stability and increased income, since there is differentiation and progression of production, cost reduction and optimization of infrastructure and manpower (Macedo, 2009).

In the implementation of ICLS, intercropping of annual crops and forages is common, mainly from the Urochloa gender, a favorite among producers, especially in the cerrado region (Kluthcouski \& Aidar, 2003). Among the annual crops, maize is the most used in intercropping because of its cultivation tradition, the high number of commercial cultivars adapted to different regions of the country and its aptitude for crops integrated with forage (Dan et al., 2012). The species of the Urochloa genus are preferably used because they easily adapt to such integration(Adegas et al., 2011), since they have low accumulation of biomass in the first 45 days after germination (Portes et al., 2000), but rapid production of biomass subsequently and tolerance to moderate shade, favoring the formation of pasture (Ikeda et al., 2013).

The success of the intercropping of maize and Brachiaria is related to the differential of crops initial growth (De Oliveira et al., 2011). Although the initial growth of Brachiaria is slower than for maize, it must be properly managed in order to avoid the interference effects. One of the most widely used strategies has been the use of reduced herbicide doses, with the aim of regulating the forage growth without damaging the weed management and ensure a satisfactory maize yield (Dan et al., 2011). In this sense, intercropping success is associated with Brachiaria susceptibility to the herbicide (Brighenti et al., 2011) and directly related to the dose, the species and the vegetative stage of the forage at the time of application.

Among all methods of weed control, the chemical one stands out for its efficiency, less use of manpower and consequently lower cost (Model \& Fraveto, 2010). Chemical weed control in maize was performed, often with herbicides such as atrazine, nicosulfuron, mesotrione and tembotrione (Karam, 2004; Jakelaitis et al., 2005). However, with the release of the use of transgenic maize cultivars resistant to glyphosate herbicide, there was a growing adoption of this herbicide for weed control in the crop.

Glyphosate is a systemic, non-selective herbicide, belonging to the class of derivatives of glycine amino acid, which acts in inhibiting 5-enolpyruvylshikimate-3-phosphate (EPSP) synthase, a key enzyme in the synthesis of amino acids tyrosine, tryptophan and phenylalanine (Trezzi et al., 2001). It has a broad spectrum of action on annual and perennial monocotyledons and eudicotyledons. It is believed that, in underdoses, glyphosate can be used to manage Urochloa brizantha in order to reduce interference of this forage on maize in an intercropping system.

Given the above, the objective was to evaluate the use of glyphosate in the management of Brachiaria intercropped with maize.

\section{MATERIALS AND METHODS}

The experiment was carried out from October 2011 to March 2012 in the Brazilian city of Viçosa, MG. The area was in fallow since the last maize culture in the 2010/2011 crop, harvested in March. The climate in the area is humid subtropical, with dry winter and hot summer, according to the Köppen-Geiger climate classification system. Climate data collected in the experimental area during the research are presented in Figure 1.

The soil was classified as clayey ultisol (Table 1). The fertilization at planting was done with the application of 20, 120 and $90 \mathrm{~kg} \mathrm{ha}^{-1}$ of $\mathrm{N}, \mathrm{P}_{2} \mathrm{O}_{5}$ and $\mathrm{K}_{2} \mathrm{O}$, respectively, distributed over the maize planting row. The side dressing consisted of the application of $300 \mathrm{~kg} \mathrm{ha}^{-1}$ of $\mathrm{N}$ as urea, applied when the maize had six fully expanded leaves.

The experiment was conducted in a randomized block design with four replications. The treatments were arranged in a $5 \times 2+2$ 


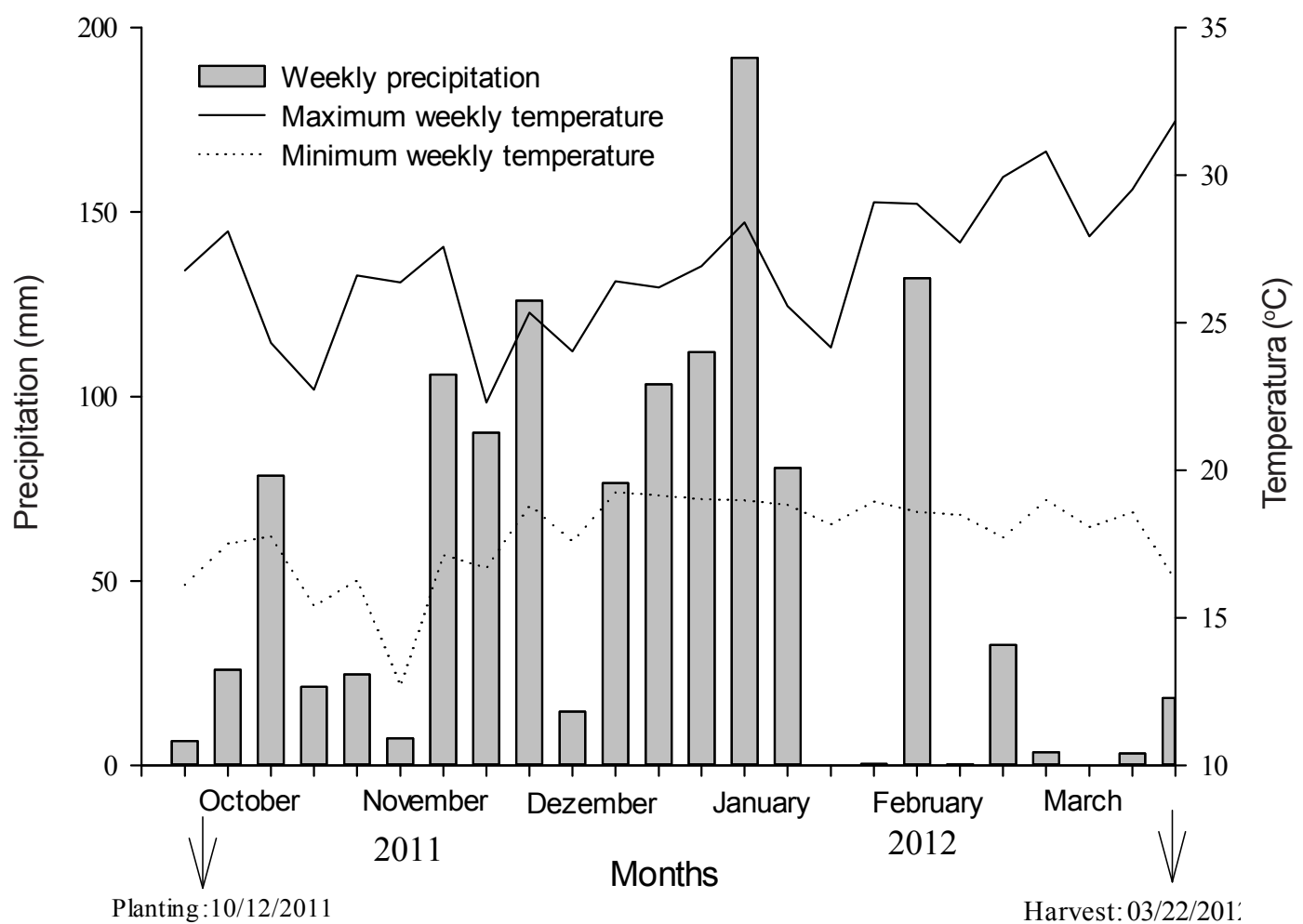

Figure 1 - Rainfall and average weekly temperatures during the period when the experiment was carried out.

Table 1 - Physical and chemical characteristics of the $0-20 \mathrm{~cm}$ soil layer before establishing the experiment

\begin{tabular}{|c|c|c|c|c|c|c|c|c|c|c|c|c|}
\hline \multirow{2}{*}{$\begin{array}{c}\mathrm{pH} \\
\left(\mathrm{H}_{2} \mathrm{O}\right) \\
\end{array}$} & $\mathrm{P}$ & $\mathrm{K}$ & $\mathrm{Ca}$ & $\mathrm{Mg}$ & $\mathrm{Al}$ & $\mathrm{H}+\mathrm{Al}$ & SB & (t) & $(\mathrm{T})$ & $\mathrm{V}$ & $\mathrm{m}$ & $\mathrm{MO}$ \\
\hline & \multicolumn{3}{|c|}{$\left(\mathrm{mg} \mathrm{dm}^{-3}\right)$} & \multicolumn{6}{|c|}{$\left(\mathrm{cmol}_{\mathrm{c}} \mathrm{dm}^{-3}\right)$} & \multicolumn{2}{|c|}{$(\%)$} & $\left(\right.$ dag kg $\left.^{-1}\right)$ \\
\hline 5.6 & 5.9 & 64 & 2.0 & 0.8 & 0.3 & 3.3 & 2.96 & 3.26 & 6.26 & 47 & 9 & 2.6 \\
\hline \multicolumn{4}{|c|}{ Granulometry (\%) } & \multicolumn{3}{|c|}{ Clay $=43$} & \multicolumn{3}{|c|}{ Silt $=14$} & \multicolumn{3}{|c|}{ Sand $=43$} \\
\hline
\end{tabular}

Analyses carried out at Laboratório de Análises de Solo Viçosa (Laboratory of Soil Analysis in the Brazilian city of Viçosa), according to the methodology of Empresa Brasileira de Pesquisa Agropecuária (Brazilian Corporation of Agricultural Research) - Embrapa (1997).

factorial arrangement, the first factor corresponding to the doses of glyphosate $\left(48,96,144,240,480 \mathrm{~g} \mathrm{ha}^{-1}\right.$ of the acid equivalent (a.e)) and the second one to the vegetative stages of the Brachiaria at the time of application (Stage 1: 2 tillers and Stage 2: 4 tillers). In addition, one weeded control and a control without herbicide application were added.

To install the experiment, the direct sowing system was used, and the prior desiccation of the vegetation area was performed by applying the mix in a glyphosate tank $\left(1,080 \mathrm{~g} \mathrm{ha}^{-1}\right.$ a.e. $)+2,4-$ Dichlorophenoxyacetic acid $\left(0.80 \mathrm{~L} \mathrm{ha}^{-1}\right)$, ten days before planting the crops. The DKB 390 maize hybrid was sown on October 20, 2011 with a Semeato SHM 11/13 multi-seeder, with sowing capacity of five plant rows spaced at $0.50 \mathrm{~m}$, with a total population of 60,000 plants per hectare.

On the same date of planting maize, the manual sowing of Urochloa brizantha (BRS Piatã - VC 76\%) was also held in the same crop row at a density of $6 \mathrm{~kg}$ of seeds per hectare. 
The experimental plots consisted of 12 rows of maize $5 \mathrm{~m}$ long, totaling $30 \mathrm{~m}^{2}$. The assessed floor area of the plot consisted of eight central rows, discarding $1 \mathrm{~m}$ from each end, representing $12 \mathrm{~m}^{2}$.

Glyphosate applications in postemergence were done at 20 and 35 days after planting, at which time maize plants had four and six fully expanded leaves, and Brachiaria had two and four tillers, respectively. A knapsack sprayer pressurized with $\mathrm{CO}_{2}$ at $250 \mathrm{kPa}$ was used, equipped with 110.02 "fan"-type two-nozzle spray boom, spaced $0.50 \mathrm{~m}$, and a spray mix volume equivalent to $200 \mathrm{~L} \mathrm{ha}^{-1}$.

Visual symptoms of Brachiaria intoxication were evaluated at 15 days after herbicide application. Grades criteria on a scale of 0 to $100 \%$ were used, where zero corresponds to no injury and 100 corresponds to the death of the plants.

At 60 days after emergence (DAE), at maize flowering, the height of 10 maize plants per plot was evaluated and also 5 maize plants were collected to determine the dry matter of shoot (DMS). DMS was obtained from drying in a forced air circulation oven $\left(70 \pm 2{ }^{\circ} \mathrm{C}\right)$ until reaching constant weight, followed by weighing the dried plant tissue, on an precision weighing balance of $0.01 \mathrm{~g}$.

Maize was manually harvested at $150 \mathrm{DAE}$, the Thousand Grain Weight (TGW) was determined and productivity was corrected to $13 \%$ moisture. On this occasion, ease of maize crop was analyzed by means of grades ranging from 1 to 4 , in which the following characteristics were observed: Grade 1: Easy harvest - with Brachiaria reaching a maximum height of $20 \mathrm{~cm}$; Grade 2: Regular harvest with Brachiaria reaching height between 20 and $60 \mathrm{~cm}$; Grade 3: Poor harvest - with Brachiaria reaching height between $60 \mathrm{~cm}$ and the maize ear height $(110 \mathrm{~cm})$; and Grade 4: Compromised mechanical harvesting - with Brachiaria reaching greater height than the maize ear height $(110 \mathrm{~cm})$. The number of plants, the number of tillers and the Brachiaria dry matter were also determined by means of this shoot collection in four rows of the floor area, each with $2 \mathrm{~m}$ linear $\left(4 \mathrm{~m}^{2}\right)$.

For the harvest grade variable, a descriptive analysis of the results was done.
Other data were submitted to analysis of variance and, when significant, they were analyzed using regression and Dunnett's test. The Dunnett's test $(\mathrm{p}<0.05)$ was carried out to compare the treatments with the weeded control and the control without application.

\section{RESULTS AND DISCUSSION}

\section{Brachiaria poisoning and growth}

Glyphosate at lower doses caused a reduction in the number of Brachiaria plants when applied at the stage of two tillers (Figure 2A). The highest dose of glyphosate (480 $\mathrm{g} \mathrm{ha}^{-1}$ a.e.) caused the death of the forage, regardless of the application time. Urochloa brizantha, being a forage of seminiferous propagation and initially having little reserves, is more sensitive to glyphosate in the early stages of development (Santos et al., 2007).

Increasing doses of glyphosate, when applied in the first vegetative stage of Brachiaria, linearly reduced the number of tillers of the forage (Figure 2B). As observed for the number of plants (Figure 2A), the application of the herbicide in the more advanced stage of development reduced the number of tillers only in doses higher than $200 \mathrm{~g} \mathrm{ha}^{-1}$ a.e.

Visual symptoms of intoxication (phytotoxicity) of Brachiaria were intensified by the increase of the glyphosate doses (Figure 2C) in both vegetative stages. The symptoms were characterized by chlorosis in leaves and tillers, followed by necrosis when used higher doses of herbicide. The application of the lowest dose of glyphosate (48 $\mathrm{g} \mathrm{ha}^{-1}$ a.e.) in the stage of four tillers of Brachiaria stage caused low toxicity to the forage plants. However, the higher dose of the product caused death of plants, regardless of the application stage. The tolerance of Brachiaria to lower glyphosate doses, especially when having four tillers, is probably due to greater accumulation of plant reserves with their further development.

The dry matter of the shoot of Brachiaria was reduced with increasing glyphosate dose in both growth stages (Figure 2D). This reduction was greater when the herbicide was applied in the stage of two leaves of the 

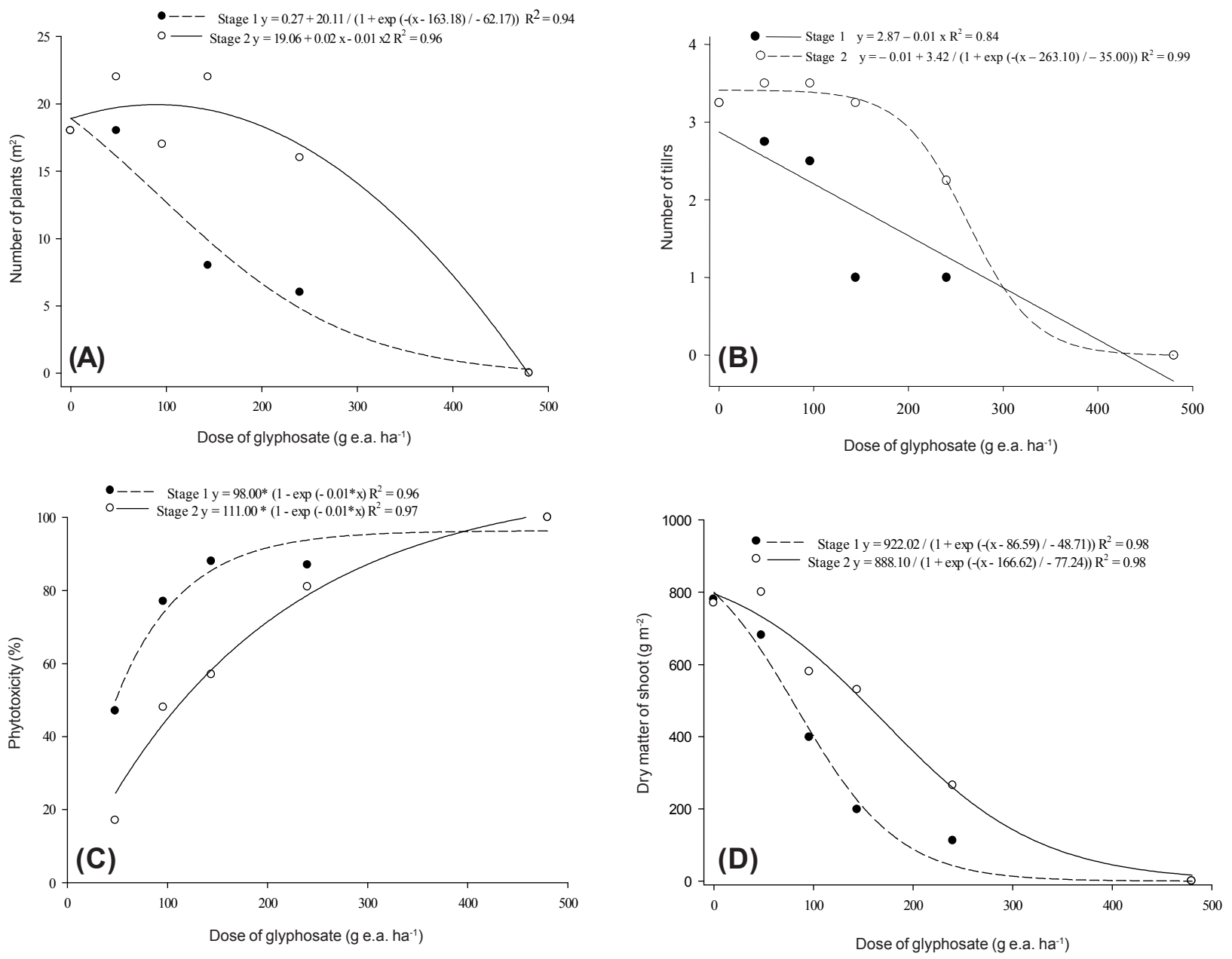

Figure 2 - Number of plants (A), number of tillers (B), phytotoxicity (C) and dry matter of shoot (D) of Urochloa brizantha, seeded at a density of $6 \mathrm{~kg}$ seeds ha-1, in intercropping with maize and subjected to applications of glyphosate doses in two vegetative stages (Stage 1: 2 tillers; Stage 2: 4 tillers).

forage, probably because of the species lower development. The growth reduction is related to the glyphosate mechanism of action which, by disrupting the shikimic acid pathway, responsible for the utilization of approximately $20 \%$ of carbon fixed in the plant, results in loss of carbon available for further cell reactions in the plant (Kishore \& Shah, 1988). This way, the growth of Brachiaria is temporarily ceased when low doses of the herbicide are applied, while high doses impair the plant metabolism, causing its death, as observed at the dose of $480 \mathrm{~g} \mathrm{ha}^{-1}$ a.e.

The number of plants and tillers of Brachiaria was reduced, compared to the control without application, when doses 144 , 240 and $480 \mathrm{~g} \mathrm{ha}^{-1}$ a.e were applied. in the stage of two tillers and of $480 \mathrm{~g} \mathrm{ha}^{-1}$ a.e. in the stage of four tillers (Table 2). However, the application in the stage of two tillers negatively affected the dry matter of the forage from the dose of $96 \mathrm{~g} \mathrm{ha}^{-1}$ a.e., while in the stage of four tillers such effect occurred only from the dose of $240 \mathrm{~g} \mathrm{ha}^{-1}$ a.e.

In the maize and Brachiaria intercropping the objective was, at first, to avoid the interference of the forage on maize, to increase the production of crop grains yield, which helps in reducing pasture establishment costs. Thus, it is noted that in the stage of two tillers, the glyphosate dose of $96 \mathrm{~g} \mathrm{ha}^{-1}$ a.e. was sufficient to reduce by approximately $50 \%$ the forage dry matter and should be considered the maximum for application at this stage, since higher doses 
Table 2 - Number of plants, number of tillers and dry matter of shoot of the Brachiaria intercropped with maize and submitted to the application of glyphosate doses in stages of two and four tillers, compared to control without application

\begin{tabular}{|c|c|c|c|c|c|c|}
\hline \multirow{2}{*}{ Dose } & \multicolumn{2}{|c|}{ Number of plants } & \multicolumn{2}{|c|}{ Number of tillers } & \multicolumn{2}{|c|}{ Dry matter of shoot $\left(\mathrm{g} \mathrm{m}^{-2}\right)$} \\
\hline & \multicolumn{6}{|c|}{ Stage of application (tillers) } \\
\hline (g. a.e. ha $^{-1}$ ) & 2 & 4 & 2 & 4 & 2 & 4 \\
\hline Control without application & \multicolumn{2}{|c|}{18.00} & \multicolumn{2}{|c|}{3.25} & \multicolumn{2}{|c|}{770.00} \\
\hline 48 & 18.00 & 22.00 & 2.75 & 3.50 & 673.33 & 797.50 \\
\hline 96 & 18.00 & 18.00 & 2.50 & 3.50 & $400.50^{*}$ & 575.00 \\
\hline 144 & $9.00 *$ & 22.00 & $1.00 *$ & 3.25 & $190.00^{*}$ & 525.00 \\
\hline 240 & $6.00 *$ & 16.00 & $1.00 *$ & 2.25 & $110.00^{*}$ & $252.50 *$ \\
\hline 480 & $0.00 *$ & $0.00 *$ & $0.00 *$ & $0.00^{*}$ & $0.00 *$ & $0.00^{*}$ \\
\hline Mean & 10.2 & 13.6 & 1.45 & 2.50 & 274.77 & 430.00 \\
\hline $\mathrm{CV}(\%)$ & \multicolumn{2}{|c|}{12.22} & \multicolumn{2}{|c|}{24.02} & \multicolumn{2}{|c|}{11.06} \\
\hline
\end{tabular}

Means followed by $*$ in the column differ from the control at $5 \%$ probability by the Dunnett's test. CV: coefficient of variation.

dramatically reduced the number of plants and tillers and could jeopardize the formation of the pasture after the maize harvest. In the stage of four tillers, doses close to $160 \mathrm{~g} \mathrm{ha}^{-1}$ a.e. caused a 50\% reduction of the DMS and slightly altered the number of tillers and plants. The application of glyphosate in the stage of two tiller of the Brachiaria represents savings of $40 \%$ in herbicide dose.

\section{Maize growth and production components}

The maize dry matter of the shoot was negatively affected by the interference of the Brachiaria when there was no application of glyphosate (Figure 3A). Increasing the dose of the product increased the dry matter of the crop, reaching maximum values near the dose of $144 \mathrm{~g} \mathrm{ha}^{-1}$ a.e. for the stage of two tillers. The application of larger doses of the herbicide at this stage reduced the forage competition and therefore provided greater maize growth in relation to the application in the stage of four tillers.

The maize plants height was not affected by the glyphosate doses in the two stages of application (Figure 3B). However, late application of the herbicide increased the maize plants height. This result, together with those obtained for dry matter of the shoot (Figure 3A), indicates that there was shading of maize plants when in competition with Brachiaria for a longer period of time. This mechanism is used on maize in order to avoid competition for light with other plants (Iptas \& Acar, 2006).
The application of higher doses of glyphosate increased the maize Thousand Grain Weight (TGW), whatever the application stage (Figure $3 \mathrm{C}$ ). The herbicide doses that caused $50 \%$ increase in the maize Thousand Grain Weight (TGW) were 158.74 and $157.48 \mathrm{~g} \mathrm{ha}{ }^{1}$ a.e. for the stages of two and four tillers of Brachiaria, respectively. The lower Thousand Grain Weight (TGW), found in the absence of herbicide application, is due to the interference of Brachiaria on maize, as reported by Rizzardi \& Pires (1996).

The maize grain yield was increased by the application of glyphosate in both vegetative stages of Brachiaria (Figure 3D). The overall gain in productivity by the application of glyphosate, compared to the control without application, was 474.55 and $564.87 \mathrm{~kg} \mathrm{ha}^{-1}$ when applied in the stages of two and four tillers, respectively. Lower herbicide dose can be used in the stage of two tillers, compared to the stage of four tillers, so that maximum yield be reached.

The total reduction in maize yields caused by the Brachiaria interference was less than $5 \%$, irrespective of the glyphosate application timing (Figure 3D). In the present study, this is due to the use of reduced inter-row spacing $(0.50 \mathrm{~m})$ and the consequent early ground cover, which helped in the crop control of Brachiaria. These results are lower than those observed in other studies on maize and Brachiaria intercropping (Jakelaitis et al., 2005; Cruz et al., 2009; Adegas et al., 2011); however, they corroborate other research, in 
that the reductions in maize yield intercropped with Brachiaria in the row or inter-rows are between 0 and 5\% (Borghi \& Crusciol, 2007; Leonel et al., 2009).

Compared to the weeded control, it was found that the dry matter of the shoot, the Thousand Grain Weight (TGW) and productivity of maize grains were not affected by time of application and dose of glyphosate (Table 3). However, the maize height was increased when application was 48, 96 and $144 \mathrm{~g}^{\text {ha }}{ }^{-1}$ a.e. in the stage of four tillers of maize. This increased maize growth, represented by the largest height of the plants, may be a crop response to competition for light. Probably the maize shading is related to a strategy to escape the competition for light with Brachiaria, which, as previously reported, had higher
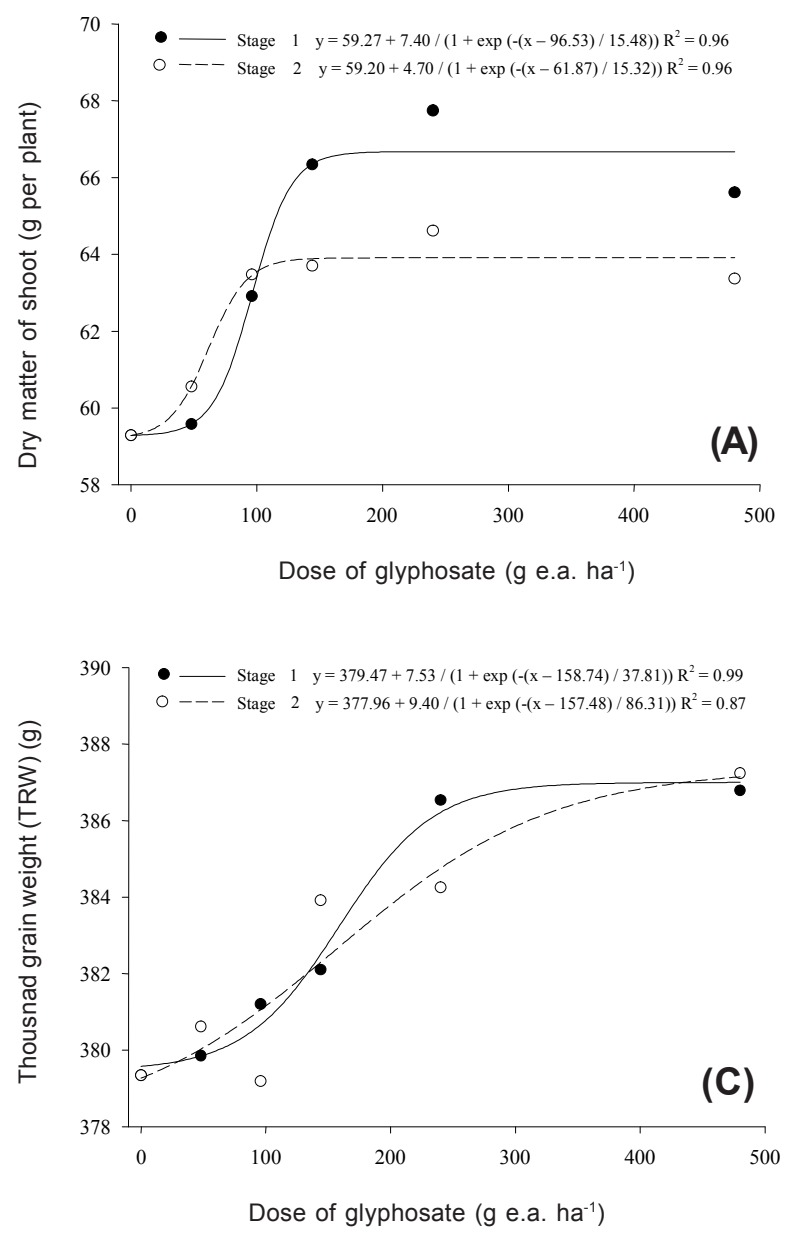

growth in lower glyphosate doses applied in the stage of four tillers.

One factor often overlooked by recent research on the intercropping between maize and Brachiaria is the feasibility of mechanical harvesting of grains at the end of the maize cycle. The forage overgrowth can derail mechanized harvesting if it achieves the height of the maize ear insertion, as it will increase the risk of machine bushing. It was observed, in Figure 4, that the maize mechanical harvesting is hampered in the absence of glyphosate application. The highest grades were obtained when the herbicide was applied in the stage of four tillers of forage and are related to the lower maize production (Figure 3D) and also the forage fastest growth (Figure 2D). The grades close to 3 alert to this
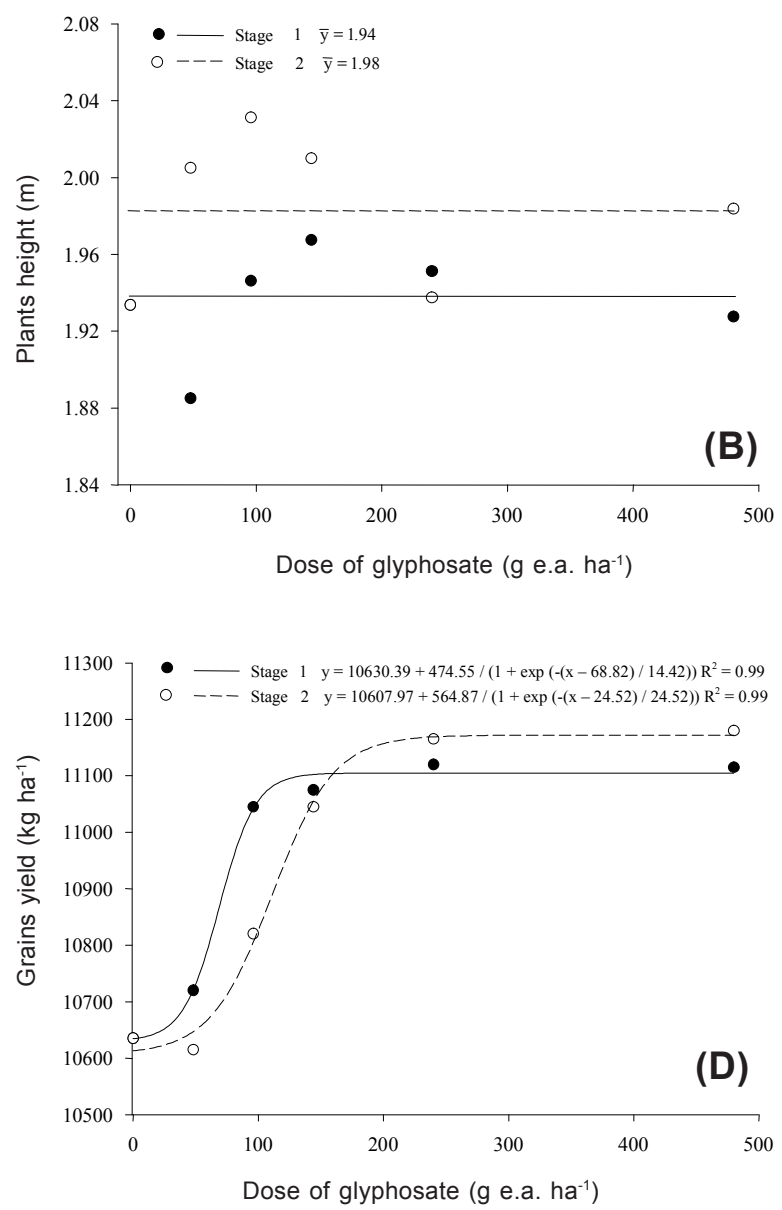

Figure 3 - Dry matter of the shoot (A), plant height (B), Thousand Grain Weight (TGW) (C) and grain yield (D) of maize intercropped with Urochloa brizantha in the density of $6 \mathrm{~kg}$ seeds ha ${ }^{-1}$, and submitted to glyphosate doses applications in two vegetative stages of the forage (Stage 1: 2 tillers; Stage 2: 4 tillers). 
Table 3 - Height, dry matter of shoots, Thousand Grain Weight (TGW) and maize grains yield in intercropping with Brachiaria subjected to glyphosate doses application in stages of two and four tillers, compared to weeded control

\begin{tabular}{|c|c|c|c|c|c|c|c|c|}
\hline \multirow[t]{2}{*}{ Dose } & \multicolumn{2}{|c|}{$\begin{array}{l}\text { Height } \\
\text { (m) }\end{array}$} & \multicolumn{2}{|c|}{$\begin{array}{c}\text { Dry matter of } \\
\text { shoot }(\mathrm{g})\end{array}$} & \multicolumn{2}{|c|}{$\begin{array}{c}\text { Thousand Grain Weight } \\
(\mathrm{TGW})(\mathrm{g})\end{array}$} & \multicolumn{2}{|c|}{$\begin{array}{l}\text { Grains yield } \\
\left(\mathrm{kg} \mathrm{ha}^{-1}\right)\end{array}$} \\
\hline & \multicolumn{8}{|c|}{ Stage of application (tillers) } \\
\hline$\left(\right.$ g a.e. ha $\left.^{-1}\right)$ & 2 & 4 & 2 & 4 & 2 & 4 & 2 & 4 \\
\hline Weeded control & \multicolumn{2}{|c|}{1.82} & \multicolumn{2}{|c|}{177.86} & \multicolumn{2}{|c|}{379.40} & \multicolumn{2}{|c|}{10635.00} \\
\hline 48 & 1.88 & $2.00 *$ & 176.15 & 181.66 & 379.90 & 379.60 & 10720.00 & 10615.00 \\
\hline 96 & 1.94 & $2.03 *$ & 178.73 & 190.41 & 381.20 & 379.20 & 11045.00 & 10820.00 \\
\hline 144 & 1.96 & $2.01 *$ & 199.01 & 191.09 & 382.10 & 383.90 & 11075.00 & 11045.00 \\
\hline 240 & 1.95 & 1.95 & 203.24 & 193.86 & 386.50 & 384.30 & 11120.00 & 11165.00 \\
\hline 480 & 1.92 & 1.98 & 196.83 & 190.09 & 386.80 & 387.20 & 11115.00 & 11180.00 \\
\hline Mean & 1.94 & 1.99 & 190.79 & 189.42 & 383.30 & 382.80 & 11015.00 & 10965.00 \\
\hline $\mathrm{CV}(\%)$ & \multicolumn{2}{|c|}{4.48} & \multicolumn{2}{|c|}{14.07} & \multicolumn{2}{|c|}{3.55} & \multicolumn{2}{|c|}{7.39} \\
\hline
\end{tabular}

Means followed by $*$ in the column differ from the control at $5 \%$ probability by the Dunnett's test. CV: coefficient of variation.
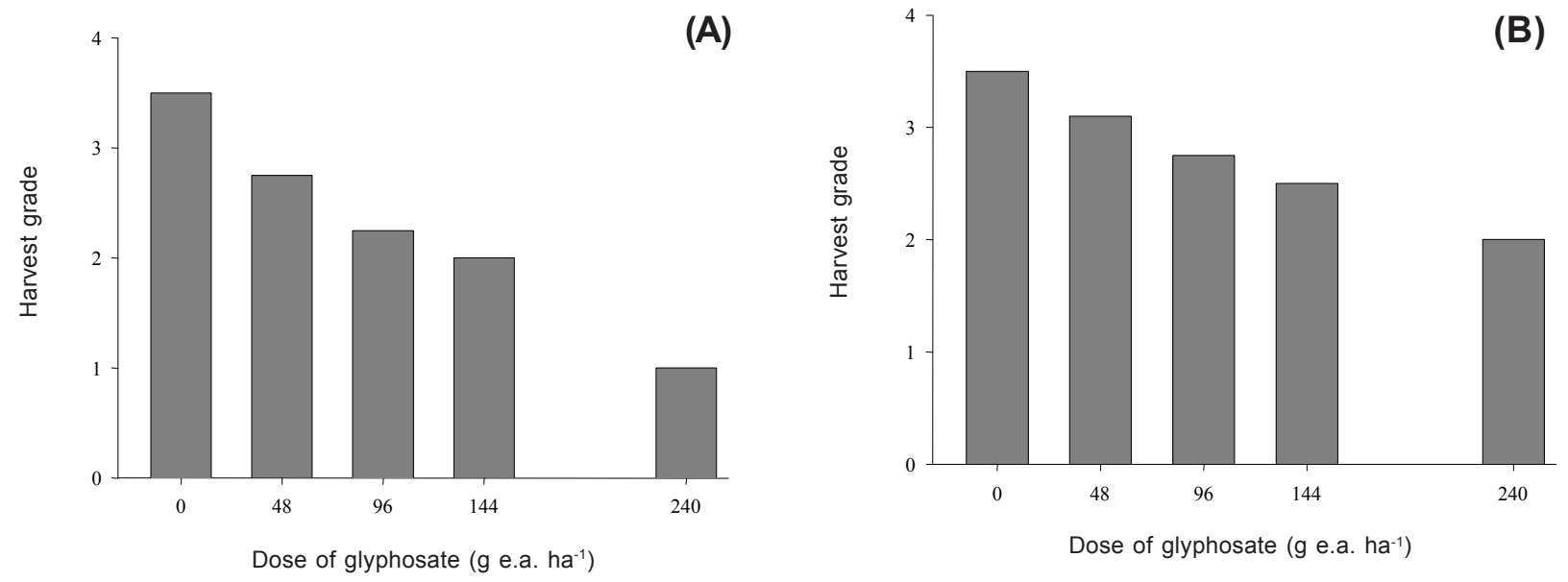

Figure 4 - Maize harvest grade in an intercropping system with Brachiaria under different doses of glyphosate in two development stages of the forage: 2 (A) and 4 (B) tillers. Grade 1: easy harvest; Grade 2: regular harvest; Grade 3: poor harvest; Grade 4: compromised mechanical harvesting.

aspect in the intercropping implementation, and the delay in harvesting can worsen this rate by the continuous and intense growth of the forage after senescence of the crop.

The results indicate the potential of glyphosate use as growth reducer of Brachiaria in intercropping with resistant maize. When applied to the stage of two tillers, the dose of $96 \mathrm{~g} \mathrm{ha}^{-1}$ a.e. reduces the forage growth and ensures good production rates of maize. However, for the stage of four tillers of Brachiaria, the more appropriated dose is $144 \mathrm{~g} \mathrm{ha}^{-1}$ a.e. in order to reduce growth without affecting the harvest and the final production of maize grains.

\section{LITERATURECITED}

ADEGAS, F. S. et al. Manejo de plantas daninhas em milho safrinha em cultivo solteiro ou consorciado à braquiária ruziziensis. Pesq. Agropec. Bras., v. 46, n. 10, p. 1226-1233, 2011.

BORGHI, E.; CRUSCIOL, C. A. C. Produtividade de milho, espaçamento e modalidade de consorciação com Brachiaria brizantha em sistema plantio direto. Pesq. Agropec. Bras., v. 42, n. 2, p. 163-171, 2007. 
BRIGHENTI, A. M. et al. Suscetibilidade diferencial de espécies de braquiária ao herbicida glifosato. Pesq. Agropec. Bras., v. 46, n. 10, p. 1241-1246, 2011.

COSTA, N. R. et al. Adubação nitrogenada no consórcio de milho com duas espécies de braquiária em sistema plantio direto. Pesq. Agropec. Bras., v. 47, n. 8, p. 1038-1047, 2012.

CRUZ, S. C. S. et al. Consórcio de milho e Brachiaria decumbens em diferentes preparos de solo. Acta Sci. Agron., v. 31, n. 4, p. 633-639, 2009.

DAN, H. A. et al. Supressão imposta pelo mesotrione a Brachiaria brizantha em sistema de integração lavourapecuária. Planta Daninha, v. 29, n. 4, p. 861-867, 2011.

DAN, H. A. et al. Controle de plantas daninhas em sistemas de cultivo consorciados. R. Bras. Herbic., v. 11, n. 1, p. 108-118, 2012.

DE OLIVEIRA, P. et al. Consórcio de milho com braquiária e guandu-anão em sistema de dessecação parcial. Pesq.

Agropec. Bras., v. 46, n. 10, p. 1184-1192, 2011.

IKEDAI, F. S. et al. Interferências no consórcio de milho com Urochloa spp. Ci. Rural, v. 43, n. 10, p. 1763-1770, 2013.

IPTAS, S. et al. Effects of hybrid and row spacing on maize forage yield and quality. Plant Soil Environ., v. 52, n. 11, p. 515-522, 2006.

JAKELAITIS, A. et al. Influência de herbicidas e de sistemas de semeadura de Brachiaria brizantha consorciada com milho. Planta Daninha, v. 23, n. 1, p. 59-67, 2005.

KARAM, D.; CRUZ, M. B. Características do herbicida mesotrione na cultura do milho. Sete Lagoas: Embrapa Milho e Sorgo, 2004. 4 p. (Embrapa Milho e Sorgo.

Circular Técnica, 52).
KISHORE, G. M.; SHAH, D. M. Amino acid biosynthesis inhibitors as herbicides. Ann. Rev. Biochem., v. 57, n. 7, p. 627-663, 1988.

KLUTHCOUSKI, A.; AIDAR, H. Evolução das Atividades Lavoura-Pecuária nos Cerrados. In: Integração LavouraPecuária. Ed. KLUTCHCOUSK, A.; STONE, L.F.; AIDAR, H. - Santo Antônio de Goiás: Embrapa Arroz e Feijão, 2003. $570 \mathrm{p}$.

LEONEL, F. P. et al. Comportamento produtivo e características nutricionais do capim-braquiária cultivado em consórcio com milho. R. Bras.

Zootec., v. 38, n. 1, p. 177-189, 2009.

MACEDO, M. C. M. Integração lavoura e pecuária: o estado da arte e inovações tecnológicas. R. Bras. Zootec., v. 38, n. 13, p. 133-146, 2009.

MODEL, N. S.; FAVRETO, R. Comparação de custos de tratamentos de controle de plantas daninhas em abacaxizeiro cultivado no Rio Grande do Sul, Brasil. Pesq. Agropec. Gaúcha, v. 16, n. 1, p. 45-50, 2010.

PORTES, T. A. et al. Análise do crescimento de uma cultivar de braquiária em cultivo solteiro e consorciado com cereais. Pesq. Agropec. Bras., v. 35, n. 7, p. 1349-1358, 2000.

RIZZARDI, M. A.; PIRES, J. L. Resposta de cultivares de milho à distribuição de plantas na linha, com e sem controle de plantas daninhas. Ci. Rural, v. 26, n. 1, p. 13-17, 1996.

SANTOS, M. V. et al. Controle de Brachiaria brizantha, com uso do glyphosate, na formação de pastagem de Tifton 85 (Cynodon spp.). Planta Daninha, v. 25, n. 1, p. 149-155, 2007.

TREZZI, M. M. et al. Inibidores de EPSPS. In: VIDAL, R. A.; MEROTTO JUNIOR, A. (Ed.). Herbicidologia. Porto Alegre: Evangraf, 2001. p. 37-45. 